\title{
Enhancing graduate students' reflection in e-portfolios using the TPACK framework
}

\author{
Yu-Hui Ching, Dazhi Yang, YoungKyun Baek and Sally Baldwin \\ Boise State University
}

\begin{abstract}
When electronic portfolios (e-portfolios) are employed as summative assessments for degree granting programs, it is imperative that graduate students demonstrate their knowledge in the field to showcase learning growth and achievement of the program learning outcomes. This study examined the extent master's degree students in the field of educational technology demonstrated their technological pedagogical content knowledge (TPACK) related elements in their e-portfolio reflection, when they were guided by TPACK framework grounded instruction. Using content analysis technique and open-ended survey responses, the findings show that graduate students were able to demonstrate their interconnected technological pedagogical knowledge in their reflection to justify their competencies. In addition, graduate students had positive reactions to the opportunity to reflect through writing the reflection paper. This study contributes to the eportfolio literature by signifying the importance of providing a discipline-specific framework to guide students' reflection of learning. The TPACK grounded instruction helped graduate students stay focused on their reflection. This study also contributes to the TPACK literature by demonstrating the extent to which graduate students presented their integrated knowledge of TPACK at the end of a program driven to developing students' technology integration expertise.
\end{abstract}

\section{Introduction}

Electronic portfolios (e-portfolios) have emerged as an assessment strategy for pre-service and in-service teachers as well as professionals of various disciplines (Barrett, 2007; Joyes, Gray, \& Hartnell-Young, 2010; Liao, 2011; Wakimoto \& Lewis, 2014). The affordance of e-portfolios that makes the storage and retrieval of artefacts easier (Lin, 2008) complements the essential role of e-portfolios - helping students learn to think critically and reflectively (Thornton, Ferris, Johnson, Kidwai, \& Ching, 2011). Ideally, when creating an eportfolio, students not only collect artefacts that showcase their learning and development, but also engage in reflective reasoning of their learning growth. Through reflection, students can connect, synthesise, and evaluate their interrelated knowledge, skills, and experiences in a comprehensive way. In addition, reflection can help students integrate their learning experiences into their existing knowledge base and encourage personal and meaningful connections to their learning.

However, in reality, many e-portfolios are only organised collections of artefacts, which fail to include nurturing thoughtful reflection with insights (Hadley, 2006). Even when reflection is a required component for eportfolios, students often discuss their artefacts at a superficial level with only a description of the artefacts. Rarely do students reflect deeply to create a strong argumentative account that demonstrates their ability to connect theory with practice and that represents competencies critical to their professions. One possible reason for the lack of in-depth reflection lies in the absence of reflective thinking skills and well-guided opportunities for reflection. A consensus seems to emerge from previous studies that reflection without any guidance is mostly low in quality (Ayan \& Seferoğlu, 2011; Lai \& Calandra, 2010; Orland-Barak, 2005; Parkes \& Kajder, 2010). In this study the technological pedagogical content knowledge (TPACK) framework (Mishra \& Koehler, 2006) was selected to guide and increase the depth of reflection written by master's degree students (graduate students hereafter) in the field of educational technology for their e-portfolios as capstone projects. 


\section{Theoretical framework}

\section{E-portfolios' role in learning and assessment}

E-portfolios play an important role in assessment and learning. When functioning as summative assessment tools (Barrett, 2007; Granberg, 2010; Ritzhaupt, Ndoye, \& Parker, 2010), e-portfolios allow teacher education programs to "determine the degree to which teachers or program candidates can demonstrate that they have reached a level of competency based on professional teaching standards" (Fox, White, \& Kidd, 2011, p. 151). Programs can extract various pieces of assessment evidence of their candidates in e-portfolios, such as the learners’ reflectivity (Chen, Lumpe, \& Bishop, 2013), pedagogical decisions (Parkes, Dredger, \& Hicks, 2013), and abilities to connect theory to practice (Fox et al., 2011; Husu, Toom, \& Patrikainen, 2008). The reflection included in the e-portfolios helps reveal learners' understanding and misunderstanding of the subject, and their accounts of pedagogical related beliefs and behaviours (Parkes et al., 2013). From an assessment perspective, learners present their achievements and competencies, making an argument that they achieve the program goals and standards and fulfill their degree requirement. The program portfolios can serve as professional portfolios for future job searches (Granberg, 2010).

As learning tools, e-portfolios allow learners to document learning progress, examine and analyse the learning trajectory, and gain confidence through the realisation of growth. The creation of e-portfolios aligns with the student-centred and constructivist view of learning as it provides an environment for learners to organise and integrate various forms of learning and to construct new insights (Barrett, 2007). When creating their eportfolios, learners follow the steps of collation, selection, reflection, and connection (Parkes et al., 2013), and traverse the path of developing a "critical, evaluative, and inferential lens through which to make decisions regarding which key artefacts can serve as the most appropriate and meaningful evidence of their growth" (Parkes et al., 2013, p. 101). Learners also practise and perfect their higher-order thinking skills critical to independent and reflective thinkers, through engaging in evaluating artefacts for inclusion, formulating a structure for organising artefacts, and synthesising knowledge and skills in different areas, such as subject matter knowledge, problem-solving skills, decision-making skills, and goal setting (Kabilan \& Khan, 2012).

\section{Reflection in e-portfolios}

Reflection is a quintessential learning objective when students engage in e-portfolio creation. Especially, in the field of education, pre-service and in-service teachers are expected to grow into reflective practitioners who conscientiously examine the effectiveness of their pedagogical decisions and practices (Rickards et al., 2008; Schon, 1983). E-portfolios offer great possibilities for different types of critical reflection, such as in action, after action, written, and videotaped (Riedinger, 2006), due to their affordances to express and demonstrate learning through various ways (Fox et al., 2011; Zeichner \& Liu, 2010). Serving as a catalyst, reflection leads students to integrate knowledge, skills, and experiences, while also constructing meaning out of the various pieces of evidence they collect in their e-portfolios (Cheng \& Chau, 2013). An identified benefit of using portfolios in teacher education is integration (Barton \& Collins, 1993), defined as students' ability to make connections between theory and practice. Students use the opportunity to connect the learned knowledge and skills with their everyday or professional experiences. Mansvelder-Longayroux, Beijaard, and Verloop (2007) stated, "reflection in the portfolio is not only a response to a particular problem or a particular issue of teaching practice; it is also concerned with linking different experiences over time" (p. 50). In the context of using portfolios for summative assessment that calls for reflect-on-action, students are provided with the opportunity to introspect and elucidate the implicit theories that determine their practices (Chen et al., 2013).

Students of all ages display various types of reflection with varying levels of quality (Chen et al., 2013). Reflection that is not discipline-specific includes career development reflection, academic accomplishment reflection, and reflection on extra-curricular learning (Wang, 2009). In contrary, when e-portfolios are used as summative assessments, discipline-specific reflection is usually the intended goal for learners to demonstrate their disciplinary learning. Nevertheless, previous studies have shown that reflection without any guidance is mostly low in quality (Ayan \& Seferoğlu, 2011; Lai \& Calandra, 2010; Orland-Barak, 2005; Parkes \& Kajder, 
2010) and therefore may not be good evidence for assessment. Boud and Walker (1998) pointed out, "Without a focus on conceptual frameworks, learning outcomes and implications, reflection for learners can become selfreferential, inward looking and uncritical” (p. 193). In teacher education literature, research has suggested the use of scaffolding to help teachers improve the quality of their discipline-specific reflection (Lai \& Calandra, 2010; Mair, 2012). In this study, a framework guiding the development of expertise in technology integration, the TPACK framework, was selected to help guide in-depth reflection of graduate students in the field of educational technology for their e-portfolios.

\section{TPACK framework guides reflection}

The TPACK framework has emerged to "capture some of the essential qualities of knowledge required by teachers for technology integration in their teaching, while addressing the complex, multifaceted and situated nature of teacher knowledge" (Mishra \& Koehler, 2006, p. 1017). The TPACK framework (Mishra \& Koehler, 2006) expanded upon Shulman's (1986) conception of teaching expertise as pedagogical content knowledge (PCK), and has served as a lens for understanding a teacher's expertise in technology integration. The TPACK framework (see Figure 1) identifies three main knowledge elements and four interceptions between the main elements. The three main elements consist of technological knowledge (TK) concerning knowledge of technological tools, pedagogical knowledge (PK) concerning methods and processes of teaching, and content knowledge (CK) concerning knowledge of the subject matter. The interceptions between these main knowledge sources form technological pedagogical knowledge (TPK) concerning knowledge of implementing different teaching methods using technological tools, the pedagogical content knowledge (PCK) concerning knowledge of teaching methods to address difficulties that students face when learning the subject matter, and technological content knowledge (TCK) concerning knowledge representing subject matter using technological tools. The interception of TK, PK, and CK represents the highly integrated knowledge for using technology to implement teaching methods to address subject matter (TPACK). Researchers contend that TPACK guides effective teaching, and that the art and science of teaching lies in this highly integrated knowledge (Doering, Veletsianos, Scharber, \& Miller, 2009; Koehler \& Mishra, 2008; Mishra \& Koehler, 2006).

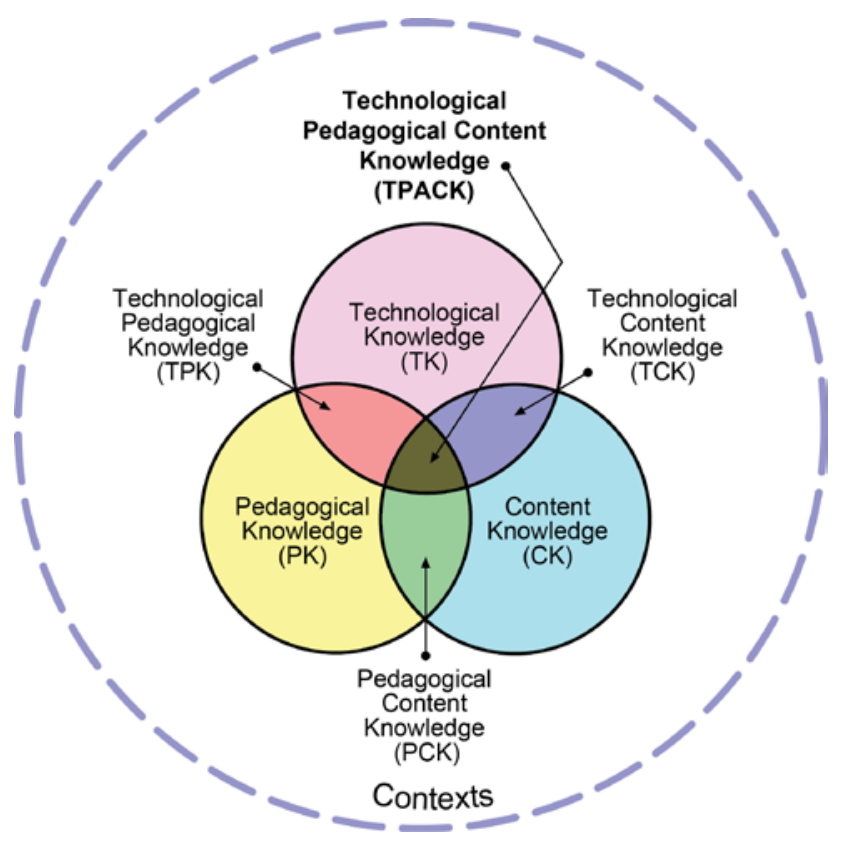

Figure 1. TPACK framework (Graphic used with permission from http://tpack.org/).

Prior research has revealed the roles these knowledge elements play in the decision making of teachers. For example, teachers' CK often impacts their pedagogical method decisions and integration of particular 
technologies (Koehler \& Mishra, 2008; Mishra \& Koehler, 2006), whereas there is only a limited link between the adoption of technology and a teacher's pedagogical method (Alvarez, Guasch, \& Espasa, 2009). Recognising the significance of integrated TPACK, research also has suggested that future interventions provide an opportunity to emphasise the interplay of these knowledge elements and to bring the elements together as one cohesive knowledge base essential to effective teaching with technology (e.g., Doering et al., 2009).

The TPACK framework emphasises the interceptions of the knowledge elements critical to teachers' technology integration. It holds great potential to guide graduate students in the field of educational technology to organise and reflect on their sophisticated knowledge, skills, and experiences related to technology integration. This discipline-specific framework also enhances more comprehensive synthesis and greater evaluation of learning. Previous studies shed light on learners' development of TPACK knowledge in educational technology related courses. For example, Koh and Divaharan (2013) found that pre-service teachers' reflections in an information, communication and technology (ICT) course showed more TK in the beginning of the instruction, compared to more knowledge integration (more PCK, TPK, TCK, and TPACK) at the end of a 3-week instruction on the integration of a whiteboard in teaching. Koehler, Mishra, and Yahya (2007) found that groups discussed TK, PK, and CK in isolation in the beginning of the semester but increased their discussions on issues related to TPK, TCK, and TPACK after they engaged in ICT design projects. However, there is dearth of literature examining the use of TPACK framework to guide students' reflection in the context of e-portfolio creation as capstone projects.

\section{Research purpose}

This study aimed to understand the extent graduate students in the field of educational technology demonstrate TPACK related knowledge elements in reflection papers written for their e-portfolios when they were guided with TPACK grounded instruction. Students' perception of the reflection process and instruction were also probed. Specifically, we asked the following research questions:

(1) To what extent did graduate students in educational technology demonstrate their TPACK related knowledge elements in the reflection papers written for their e-portfolios when they were guided with TPACK grounded instruction?

(2) How did graduate students in educational technology perceive the writing of the reflection papers for their e-portfolios?

(3) How did graduate students in educational technology perceive the TPACK grounded instruction designed to guide students' writing of their reflection paper for their e-portfolios?

\section{Research method}

The current study adopted a case study methodology to gain an in-depth understanding of the extent graduate students presented TPACK in their reflection and their perceptions of the guided instructions. Using the case study method, we were able to investigate the phenomenon within its real-life context using data from multiple sources (Yin, 2013).

\section{Participants and the context}

Participants were recruited from a north-western university in the United States. Sixteen master's degree students enrolled in two sections of the e-portfolio course in 2014 participated in this study voluntarily. Fiftysix percent of the participants were male. These participants were adult learners; about $19 \%$ were younger than 30 years old; 25\% were between 31 and 40 years old; about 31\% were between 41 and 50 years old; and 25\% were between 51 and 60 years old. Among the participants, 56\% were in-service $\mathrm{K}-12$ teachers pursuing an advanced degree to improve their teaching with technology or to further their career. The remaining participants were instructional designers in higher education or technology coaches in $\mathrm{K}-12$ settings. 
The 16-week-long e-portfolio course was hosted on the learning management system Moodle. This course served as a capstone course for a master's degree in an educational technology program. The program's learning outcomes were aligned with the 2005 version of the Association for Educational Communications and Technology (AECT) standards (Earle \& Persichittee, 2005) at the time of this study. In this class, graduate students created professional e-portfolios as capstone projects to showcase their learning growth linked to the 2005 AECT standards, and to satisfy the program exit requirement. A template portfolio site was provided to help the students focus their energy on reflection rather than on the mechanics of creating their e-portfolios. Following the template, students created their e-portfolio to include a selection of artefacts from the required and elective courses they attended, a written reflection paper, and a reflection video. The students spent four weeks completing a draft of their portfolio in the beginning of the class, and submitted the draft for faculty feedback. They then revised their portfolios and submitted them for a formal review by two faculty members in the program.

\section{Learning activity}

In their e-portfolios, students wrote a reflection paper to discuss how their artefacts demonstrated mastery of the 2005 AECT standards. The 2005 AECT standards have 20 sub-standards to which students must link their artefacts. The students were advised to choose one or more artefacts that could best represent their mastery of the sub-standards first and then write a reflection that discussed how they linked theory with practice in the creation of the artefacts. The suggested length of the reflection paper was 20 double-spaced pages. In the past, many graduate students did not write a strong reflection paper demonstrating the knowledge and skills they have learned and applied. They often superficially described what they did to create the artefacts, not showing the critical decision-making processes for the pedagogy and technology used. To address this issue, the authors designed a set of instructions to guide students' writing of their reflection papers based on the TPACK framework, including an explanation of the purpose of the reflection paper, a set of guiding questions, and annotated positive and negative examples. Table 1 presents the guiding questions that prompted graduate students to provide a description of the artefact, specify the technology and pedagogy used to create the artefact, and state the educational benefits of the selected technology and pedagogy. A brief justification on how the artefact demonstrates students' mastery of the standard follows. This design aligns with the two guiding questions provided by Hadley (2006): "What?" and “So what?" In addition, the set of questions used in this study specifically guided graduate students to reflect on both the pedagogical and technological significance of their artefacts to enable them to justify their competencies in both areas. This design also follows best practice of aligning assessment with intended learning goals of the program, developing students' PK, TK, TPK and skills. In designing the questions, we did not focus on CK in the TPACK framework as it is not an area of focus in this program. Although we did not purposefully prompt students' reflection on CK, we recognised CK as an interrelated part of the knowledge base with a critical role in graduate students' development of technology integration expertise. 
Table 1

Guiding questions for writing reflection papers

\begin{tabular}{|c|c|}
\hline \multicolumn{2}{|c|}{ Reflection prompts } \\
\hline $\begin{array}{l}\text { Artefact } \\
\text { description: }\end{array}$ & $\begin{array}{l}\text { - What is the learning context of your artefact? } \\
\text { - Who are the target learners/audience? } \\
\text { - What content area is covered in this artefact? } \\
\text { - What are the learning goals/objectives? }\end{array}$ \\
\hline Technology: & $\begin{array}{l}\text { - What technologies were used and how did you use these technologies to create } \\
\text { the artefact? } \\
\text { - What are the benefits of using these technologies to enhance student learning or } \\
\text { your teaching? }\end{array}$ \\
\hline Pedagogy: & $\begin{array}{l}\text { What theories/methods/strategies (e.g., learning theories, instructional design } \\
\text { models and strategies, media design/development principles, graphic design } \\
\text { principles) did you use to design or create the artefact? } \\
\text { - What are the benefits of using these theories/methods/strategies to enhance } \\
\text { student learning or your teaching? }\end{array}$ \\
\hline $\begin{array}{l}\text { Brief } \\
\text { Justification: }\end{array}$ & $\begin{array}{l}\text { - Use one or two sentences to briefly justify how the artefact demonstrates your } \\
\text { mastery of the standard. } \\
\text { - [Optional, whenever it applies] How does the experience of creating this artefact } \\
\text { impact your current use of technologies and theories in your teaching/work? }\end{array}$ \\
\hline
\end{tabular}

\section{Data collection}

Two data sources were used to answer the aforementioned research questions: students' drafts of reflection papers and their responses to a survey. First, students' reflection paper drafts were analysed using content analysis to determine to what extent students demonstrated TPACK related knowledge elements in their reflection papers. The use of content analysis to analyse students' TPACK in their discourse or written reflection aligns with previous research practice (e.g., Koh \& Divaharan, 2013; So \& Kim, 2009). Content analysis is a data analysis technique that involves procedures to make valid inferences from text (Anderson, Rourke, Garrison, \& Archer, 2001). In the reflection papers, students justified their mastery of 20 sub-standards with a selection of 20 to 25 artefacts. Students' justification for AECT Standard 1.3 (Instructional Strategies) and Standard 2.2 (Audiovisual Technology) were selected for analysis due to these two standards being closely linked to technology integration and the TPACK framework. Standard 1.3 has an emphasis on pedagogy, whereas Standard 2.2 focuses more on technology. A complete sentence was used as a unit of analysis for coding, resulting in a total of 492 units of analysis from 16 reflection papers. Specifically, 248 units represented reflection for Standard 1.3, and 244 units for Standard 2.2. All the units were coded for categories using the coding scheme presented in Table 2, which was adapted from the scheme used by Koh and Divaharan (2013) and Mishra and Koehler (2006). Two raters, two of the authors, coded the units individually and then discussed differences in coding until they reached agreement. Frequencies were then calculated to examine the distribution of different knowledge elements. 
Table 2

TPACK coding scheme and examples

TPACK categories
Pedagogical knowledge (PK) -
knowledge of methods and processes
of teaching, including knowledge in
classroom management, assessment,
lesson plan development, and student
learning

Coding example

An ARCS table is a way for an instructional designer to select instruction that will engage the student with the lesson material. $\mathrm{A}=$ attention, $\mathrm{R}=$ relevance of material, $\mathrm{C}=$ confidence, $\mathrm{S}=$ satisfaction.

The scavenger hunt instructional strategy is also effective in increasing student interest in the activity because the learners perceive it as a game or competition.

Technology knowledge (TK) features and functions of the technological tool of concern

Content knowledge (CK) knowledge about the subject matter to be learned or taught

Technological pedagogical knowledge (TPK) - knowledge of implementing different teaching methods using technological tools

Pedagogical content knowledge (PCK) - knowledge of teaching methods to address difficulties that students face in learning the subject matter

Technological content knowledge (TCK) - knowledge of subject matter representation using the technological tool of concern

Technological pedagogical and content knowledge (TPACK) knowledge of using the technological tool of concern in conjunction with specific teaching methods for different types of subject matter

Other - information not related to TPACK or lack of specificity
This interactive game was created using Adobe Flash and Illustrator.

Voice-overs were created using my voice and the assistance of voice altering software for the different characters.

What a better way to visit the World's 5 tallest buildings! The story explores concepts around the irrational number pi (3.141....).

I used Microsoft Word to create this document - a print piece for the instructor to refer to while planning the class.

The [virtual] tour includes photos, videos and links to online resources to support students in responding to reflection prompts within a digital journal they will create for the assignment.

For example, to give students confidence in learning about Twitter (C), the instructor will explain that the class will be made up of many small steps and they will have the opportunity to master one before moving on to the next.

Often, $6^{\text {th }}$ grade students have very little knowledge of copyright and frequently violate copyright law when producing projects and other school assignments.

My webquest was based on the journey of Lewis and Clark. By using GoAnimate, I was able to create an animation this past year on classroom rules.

They can then use the spreadsheet to help them as they compare and contrast the two wars.

In this activity students visit different websites to research and find the answer to a guiding questions regarding the topic of Waste in Our World.

This artefact was extremely helpful to me and is something that I will use in future as I develop classes.

[This] was my first class that showed me how to use Dreamweaver and create web pages.

With my background being geared toward adult learning, I took a chance and stepped out of my comfort level to design this game. 
Second, a survey consisting of open-ended questions was administered after students submitted their reflection paper drafts. The open-ended questions elicited learners' perceptions of the writing experiences and the reflection paper instruction. We grouped the responses of the open-ended survey questions into themes first, and then evaluated the fit between each student response and the themes. We then tallied the response frequency of each theme.

\section{Results}

\section{Students' TPACK demonstrated in their reflection papers}

Students' reflection and justification of their competencies on two AECT standards - Standard 1.3 (Instructional Strategy) and Standard 2.2 (Audiovisual Technology) - were selected for content analysis and coded using the TPACK coding scheme. The findings show that the participating students demonstrated all seven TPACK categories in their reflection and justification of mastery for both standards, even though the CK related categories were not prompted in the instruction. Overall, PK, TPK, and TK were the categories of knowledge students generated most frequently across the two standards, whereas CK and TCK were the least generated categories.

Among the 248 units in the Standard 1.3 (Instructional Strategy) section, students generated PK the most (42\% of 248 units), followed by TPK (18\%). Among the 244 units in the Standard 2.2 (Audiovisual Technology) section, the participating students generated TPK the most (30\%), followed by TK (1\%). See Figure 2 for detailed percentage breakdowns of students' justification by TPACK category.

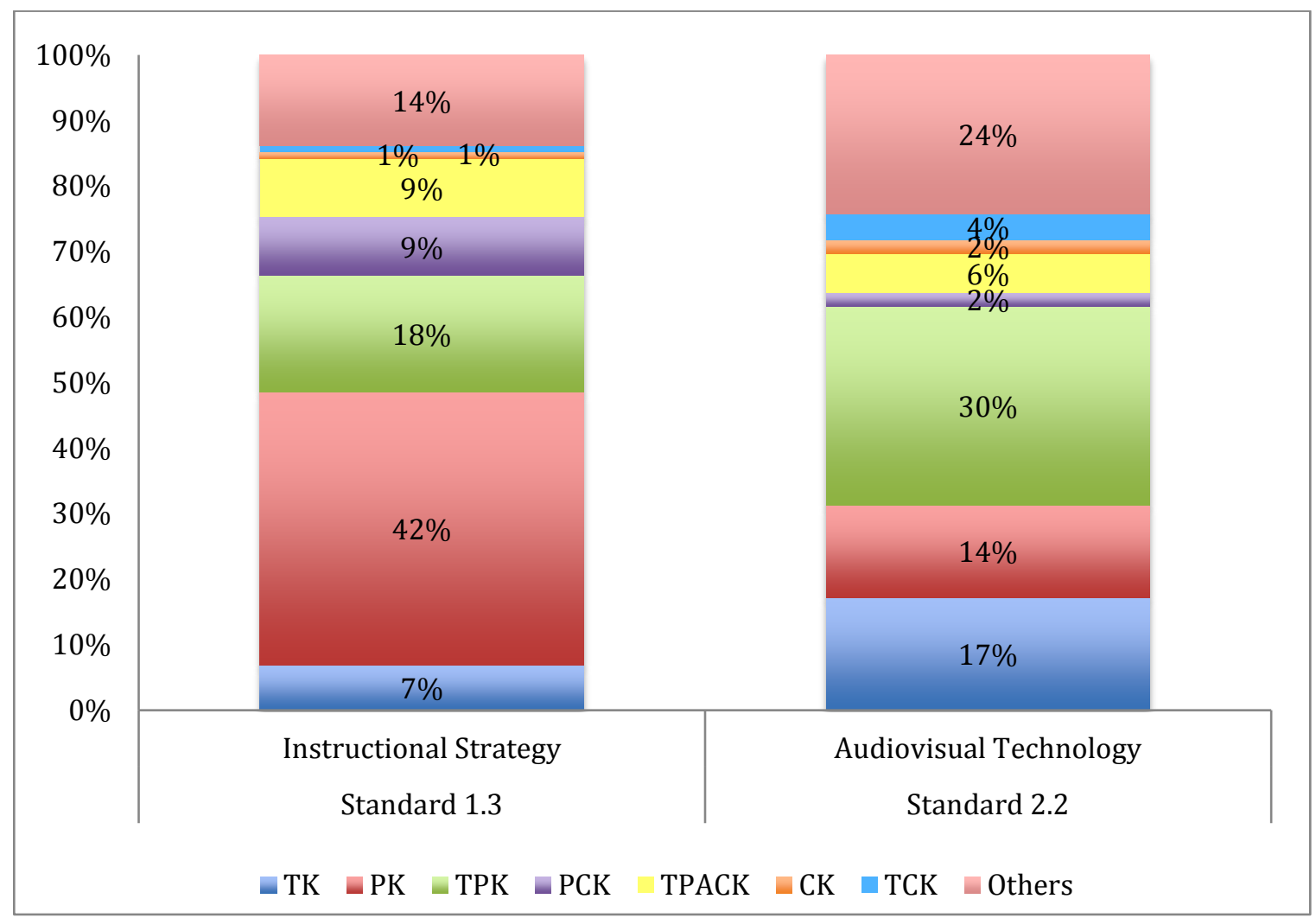

Figure 2. Percentage of graduate students' reflection by TPACK category. 
Table 2 shows the descriptive data of students' reflection by TPACK category. Students generated similar amount of reflection sentences for Standard 1.3 and Standard 2.2, with an average of 15 sentences per standard. However, students justified their competencies differently for the two standards. For Standard 1.3 (Instructional Strategy), a standard emphasising pedagogy, students generated more PK, with 6.44 sentences per student, followed by TPK, with 2.81 sentences per student. Notice that the participating students generated only 1.13 sentences in the TK category. On the other hand, for Standard 2.2 (Audiovisual Technology), a standard focusing on the use of technological tools, the participating students generated most in the category of TPK, with 4.56 sentences per student, followed by TK, with 2.65 sentences per student. In both cases, although CK is not emphasised in the instruction of the reflection paper, participating students produced a certain amount of content related reflection, including TPACK.

Table 2

Descriptive data of graduate students' justification by TPACK categories

\begin{tabular}{lcccccc}
\hline & \multicolumn{3}{c}{$\begin{array}{c}\text { Standard 1.3 } \\
\text { Instructional Strategy }\end{array}$} & \multicolumn{3}{c}{$\begin{array}{c}\text { Standard 2.2 } \\
\text { Audiovisual Technology }\end{array}$} \\
\hline MK & Mean & SD & Range & Mean & SD & Range \\
PK & 1.13 & 1.31 & 5 & 2.65 & 1.78 & 6 \\
TPK & 6.44 & 7.21 & 30 & 2.13 & 2.47 & 8 \\
& 2.81 & 2.43 & 8 & 4.56 & 3.79 & 13 \\
PCK & 1.38 & 1.50 & 5 & 0.38 & 0.72 & 2 \\
TPACK & 1.38 & 1.45 & 4 & 0.94 & 1.29 & 4 \\
CK & 0.13 & 0.34 & 1 & 0.38 & 0.86 & 3 \\
TCK & 0.13 & 0.34 & 1 & 0.56 & 0.81 & 2 \\
Other & 2.13 & 1.82 & 6 & 3.69 & 2.98 & 9 \\
Total units & 15.50 & 11.11 & 46 & 15.25 & 7.00 & 25 \\
\hline
\end{tabular}

\section{Students' positive experiences on writing the reflection paper}

Based on the survey data, the 16 students self-reported that they spent, on average, 31 hours writing their reflection paper, with a range from 10 to 90 hours. A survey question asked the participating students what they learned from writing the reflection paper. Thirty-one percent of the participants commented that they used this opportunity to reflect on all the work they did in the program. A sample comment reads, "The reflection paper was an excellent opportunity to reflect on the learning acquired throughout my time in this program."

Nineteen percent of the participants appreciated how writing the reflection paper enabled them to reflect on the connection of learning theories with their practices. One student commented that "it was fun to tie artefacts from my first few courses to theories that I learned later," and another student stated that it "enabled me to witness the growth of my understanding and evolution of my core beliefs about educational technology from theory into practice.” Another 19\% of the participants commented that writing the paper helped them realise they had learned a lot in the program. A sample comment reads, "I learned how much I had learned and created throughout the MET [Master of Educational Technology] process. It really consolidated the entire experience.” About $13 \%$ of the students pointed out that writing this reflection paper allowed them to tie their learning experiences to specific standards.

\section{Students' perceived usefulness of the TPACK grounded reflection instruction}

An analysis of the survey data shows that $71 \%$ of the participating students reported that the instructions for writing the reflection paper were helpful. The students appreciated the provided question prompts that served as a frame for approaching the writing. Two sample comments read: 
Australasian Journal of Educational Technology, 2016, 32(5).

The questions were useful prompts to help us think about the program and the work we produced or completed. Again, there is a huge amount of work to reflect upon and connect to standards. Questions help organise and focus the gathering and communication of our accomplishments.

The questions helped me to think through how the degree has made me a better educational resource developer. They also made me consider how each artefact tied to theory.

The positive and negative examples offered in the instruction were also critical in helping clarify the requirements and expectations, as reported by the participating students.

They helped me understand the level of writing that was expected and the approximate length.

The negative examples were the most helpful. They gave me some things specific to avoid.

The examples gave a practical view of how to formulate our writing in support of authentic mastery of the standards.

\section{Discussion and implications}

A case study method was used in this study to examine the extent to which graduate students demonstrated their TPACK related knowledge elements in a reflection paper written for their e-portfolios when they were guided with TPACK grounded instruction. We also examined these students' perceptions on writing the reflection paper and on the provided instruction that guided their writing. Content analysis technique was used to analyse students' reflection for two standards: one focusing on pedagogy, the other on technology. The findings indicate that the participating students were able to demonstrate their interconnected TPK successfully in their reflection for the purpose of justifying their competencies. The participating students also demonstrated TPACK related knowledge elements adaptively, according to the emphasis of the standards. When reflecting and justifying their competencies for the pedagogy-focused standard, the participants were able to produce more PK (42\%) and TPK (18\%). On the other hand, when reflecting and justifying for the technology-focused standard, the participants generated more TPK (30\%) and TK (17\%). In both cases, the participating students were able to showcase that they integrated technological and pedagogical knowledge well enough to frequently draw on the interconnected knowledge in their reflection. Research has suggested that teachers need to learn the pedagogical use of the tools to help them develop ways to integrate the tools in their own classes. They do not simply integrate technology in their classes after they learn the functions and features of the tools (Moursund \& Bielefeldt, 1999; Strudler \& Wetzel, 1999). The master's program from which the participating students were recruited aimed to develop students' expertise in technology integration. Throughout the program, students were not only engaged in learning new technological tools and instructional methods, but also were required to use the learned tools and instructional methods to design and develop teaching or learning related materials as ways to develop their interconnected TPK. When prompted to show their knowledge at the end of the program, the students were able to display their integrated TPK. In addition, the fact that students drew on different elements of knowledge to justify their competencies for two standards of distinct emphasis suggests that they were cognisant of their use of these knowledge elements. This finding contributes to the TPACK literature as it reveals the types and frequencies of graduate students' knowledge elements presented in their reflection at the end of a program intending to develop students' technology integration expertise.

Overall, the survey data on graduate students' perceptions shows that these students reacted positively to the reflection paper writing experience and the TPACK grounded reflection instruction. The reflection paper writing experience enabled them to achieve the goal of e-portfolios as summative assessment tools and served as a catalyst for reflection. With proper guidance, students valued the opportunity for reflection and engaged in critical reflective examination of their learning growth, connecting theories with practices, and realising their achievement of important competencies. Goal orientation has been suggested as an important step in learning (Abrami et al., 2008) and found to impact learners' reflective ability demonstrated in their e-portfolios (Cheng 
\& Chau, 2013). From a goal setting perspective, the reflection instruction seems to sufficiently help learners understand and set a goal of reflection to demonstrate their growth in TPACK instead of in other aspects. This finding contributes to the e-portfolio literature by demonstrating the importance of providing a disciplinespecific framework to guide graduate students' reflection. TPACK grounded instruction can help graduate students stay focused in their reflection, making it possible for assessors to extract various pieces of assessment evidence of learners' achievements, such as pedagogical decisions (Parkes et al., 2013) and their ability to connect theory to practice (Fox et al., 2011; Husu et al., 2008).

As revealed from the content analysis, students demonstrated TPACK, the most interconnected form of knowledge in the TPACK framework, less frequently in their reflection on their competencies of the two standards examined in this paper. On average, a student generated 15 sentences of reflection for a standard and about one sentence (i.e., 1.38 sentences for Standard 1.3 and .94 sentences for Standard 2.2) among the 15 sentences demonstrated TPACK. Several explanations may account for the relative low frequency of TPACK in reflections. First, this finding aligns with the program learning outcomes to develop graduate students' PK, TK, and TPK, instead of their CK. Students could take the initiative for the integration of CK but it was not required. Second, the designed question prompts in the reflection paper instruction, aligning with the program goals, did not attempt to elicit content related knowledge. Despite the impactful role of CK on teachers' decisions of the pedagogical methods and integration of particular technologies (Koehler \& Mishra, 2008; Mishra \& Koehler, 2006), in the current study, students may have followed the reflection instruction closely to demonstrate mostly their pedagogical and technological related knowledge. Third, students' less frequent reflection on CK, TCK, PCK, and TPACK in this study also reiterates the findings from previous studies (e.g., Anderson, Barham \& Northcote, 2013; Hofer \& Harris, 2012) that in-service or pre-service teachers' TPK was more obvious and frequently documented when compared with content related knowledge.

TPACK has been considered the representation of expertise of technology integration. The more quality TPACK graduate students can demonstrate in their reflection, the better they are at showcasing their expertise for their current or future profession or at job searches. However, according to the TPACK framework, TPACK is a highly integrated and complicated form of knowledge. Recognising the complicated nature of TPACK, researchers suggested the need of multiple instructional strategies to promote pre- or in-service teachers' TPACK development, such as design projects (Koh \& Divaharan, 2013) and microteaching activities (Cavin, 2008). Rubrics developed to support TPACK development could also be adopted for pedagogical scaffold (e.g., Koh, 2013). If the integration of CK into TPK is a desired learning outcome, instructional strategies or even carefully designed courses need to be in place to help students' TPACK development. For example, Habowski and Mouza (2014) found that coupling a content-specific technology integration course with extensive field experience resulted in pre-service teachers considering the interactions among TCK more frequently, compared to TPK. In addition to course-level intervention, future research may also investigate how to elicit graduate students' TPACK in reflection papers and further help them integrate their knowledge elements. For example, the guiding questions can ask graduate students to justify the use of the specific technology to help the implementation of the pedagogical method to teach specific content.

As also revealed from the content analysis, the participating students generated some reflection that cannot be classified to any of the TPACK categories (coded as "other"), due to the lack of specificity or relevancy. A sample reflection showing the lack of specificity reads, "This artefact was extremely helpful to me and is something that I will use in future as I develop classes." While the percentage of the "other" category may seem to be sizable in the students' reflection for both standards compared to other categories, we are actually quite satisfied with this finding. Our extensive teaching experiences of this portfolio course indicates that before the use of the TPACK framework to guide students' reflection, students would write more about their emotions, beliefs, or general lessons learned from creating the artefacts, rather than articulate the knowledge and skills that demonstrate their mastery of the competencies. This concurred with findings from previous studies that students generated various types of reflection with varying levels of quality when no guidance was provided (Ayan \& Seferoğlu, 2011; Chen et al., 2013; Lai \& Calandra, 2010; Orland-Barak, 2005; Parkes \& Kajder, 2010). With the guidance of the TPACK grounded instruction, students were able to represent learning growth in the form of their TPACK relevant knowledge elements. 


\section{Limitations and future research}

This case study had a limited number of participants. The majority of the participants were in-service teachers pursuing a master's degree in educational technology. The e-portfolios created were capstone projects to fulfill program requirements. Participants wrote the reflection paper to demonstrate their learning growth in the program rather than in a single course. As such, the generalisability of the findings to other contexts and other student populations needs to be further examined. Future studies could use research design to further establish the effect of the use of the TPACK framework to scaffold graduate students' reflections.

While the TPACK framework has served as a useful theoretical and analytical tool in this study, it has limitations in capturing graduate students' insightful reflection in areas other than their knowledge and skills. For example, reflection also reveals beliefs and emotions, such as "This is one of those assignments that motivated me to keep learning and using different applications," and "More importantly, I have learned that there is never just one option, if one idea does not work another will.” Research has found that teachers' beliefs and emotions have a great impact on their teaching and technology integration (Ertmer, Ottenbreit-Leftwich, Sadik, Sendurur, \& Sendurur, 2012; Kopcha, 2012). Herrington and Oliver (2000) identified attending to both positive and negative feelings about the experience as an important phase in reflective learning. Future research is encouraged to examine these aspects of reflection by combining the TPACK framework with other reflection frameworks to capture not only the knowledge aspects of learning growth, but also changes in beliefs, motivation, and emotions.

In addition, as reflection has played an important role in assisting learners to connect and integrate knowledge elements, future endeavours could explore how to infuse the TPACK grounded reflection experiences in courses throughout the program, leading to more experienced reflective learners. The use of the TPACK framework as a tool for constant reflection practices throughout a program will not only enhance students' creation of a schema for technology integration, but also shed light on assessment aspects. Programs can track individual learning growth through TPACK grounded reflection, echoing the suggestions of using TPACK for documenting educators' development in Anderson et al. (2013). Systematic analysis of how individuals develop their TPACK knowledge elements throughout the program can provide implications for program administration regarding course offerings and course design.

\section{Conclusion}

This study reveals that the participating graduate students were able to demonstrate their interconnected technological pedagogical knowledge in their reflection that justified their competencies. In addition, the students had positive reactions to the opportunity to reflect through writing the reflection paper. The results of this study verify the pedagogical benefits of employing e-portfolios as tools for summative assessments as well as for reflection. The reflection papers have been shown to be critical in consolidating learning experiences and enabling revelation of learning growth at the end of the program. This provides policy implications for using eportfolios not only for showcasing artefacts, but also for reflecting on learners' development. In addition, using the TPACK framework can guide graduate students to reflect on the interconnected TPACK knowledge base they developed at the end of their master's program in educational technology. When e-portfolios are used as summative assessments, students can also reflect on how well they have achieved the program's learning outcomes. This study contributes to the e-portfolio literature by demonstrating the importance of providing a discipline-specific framework to guide students' focused reflection. This study also contributes to the TPACK literature by showing the extent to which graduate students present their integrated knowledge of TPACK at the end of a program driven to developing students' technology integration expertise.

\section{References}

Abrami, P. C., Wade, C. A., Pillay, V., Aslan, O., Bures, E. M., \& Bentley, C. (2008). Encouraging selfregulated learning through electronic portfolios. Canadian Journal of Learning and Technology, 34(3).

Retrieved from http://www.cjlt.ca/index.php/cjlt/article/view/507/238 
Alvarez, I., Guasch, T., \& Espasa, A. (2009). University teacher roles and competencies in online learning environments: A theoretical analysis of teaching and learning practices. European Journal of Teacher Education, 32(3), 321-336. doi:10.1080/02619760802624104

Anderson, A., Barham, N., \& Northcote, M. (2013). Using the TPACK framework to unite disciplines in online learning. Australasian Journal of Educational Technology, 29(4), 548-565. http://dx.doi.org/10.14742/ajet.24

Anderson, T., Rourke, L., Garrison, D. R., \& Archer, W. (2001). Assessing teaching presence in a computer conferencing context. Journal of Asynchronous Learning Networks, 5(2). Retrieved from http://onlinelearningconsortium.org/read/journal-issues/

Ayan, D., \& Seferoğlu, G. (2011). Using electronic portfolios to promote reflective thinking in language teacher education. Educational Studies, 37(5), 513-521. doi:10.1080/03055698.2010.539782

Barrett, H. (2007). Researching electronic portfolios and learner engagement: The REFLECT initiative. Journal of Adolescent \& Adult Literacy, 50(6), 436-449. doi:10.1598/JAAL.50.6.2

Barton, J., \& Collins, A. (1993). Portfolios in teacher education. Journal of Teacher Education, 44, 200-210. Retrieved from http://jte.sagepub.com/content/44/3/200.extract

Boud, D., \& Walker, D. (1998). Promoting reflection in professional courses: The challenge of context. Studies in Higher Education, 23(2), 191-206. doi:10.1080/03075079812331380384

Cavin, R. (2008). Developing technological pedagogical content knowledge in preservice teachers through microteaching lesson study. In K. McFerrin, R. Weber, R. Carlsen, \& D. Willis (Eds.), Proceedings of the Society for Information Technology \& Teacher Education International Conference 2008 (pp. 52145220). Chesapeake, VA: Association for the Advancement of Computing in Education (AACE). Retrieved from https://www.learntechlib.org/p/28106

Chen, D., Lumpe, A. \& Bishop, D. (2013). Assessment of teacher candidate reflection in e-portfolios. In J. Herrington, A. Couros, \& V. Irvine (Eds.), Proceedings of EdMedia: World Conference on Educational Media and Technology 2013 (pp. 1872-1881). Chesapeake, VA: Association for the Advancement of Computing in Education (AACE). Retrieved from https://www.learntechlib.org/p/112224

Cheng, G., \& Chau, J. (2013). A study of the effects of goal orientation on the reflective ability of electronic portfolio users. Internet and Higher Education, 16(1), 51-56. doi:10.1016/j.iheduc.2012.01.003

Doering, A., Veletsianos, G., Scharber, C., \& Miller, C. (2009). Using the technological, pedagogical, and content knowledge framework to design online learning environments and professional development. Journal of Educational Computing Research, 41(3), 319-346. doi:10.2190/EC.41.3.d

Earle, R. S., \& Persichitte, K. A. (Eds.). (2005). Standards for the accreditation of school media specialist and educational technology specialist programs. (4th ed.). Bloomington, IN: Association for Educational Communications and Technology. Retrieved from http://c.ymcdn.com/sites/aect.siteym.com/resource/resmgr/AECT_Documents/AECTstandardsREV2005.pdf

Ertmer, P. A., Ottenbreit-Leftwich, A. T., Sadik, O., Sendurur, E., \& Sendurur, P. (2012). Teacher beliefs and technology integration practices: A critical relationship. Computers and Education, 59(2), 423-435. doi:10.1016/j.compedu.2012.02.001

Fox, R., White, C. S., \& Kidd, J. (2011). Program portfolios: Documenting teachers' growth in reflectionbased inquiry. Teachers and Teaching, 17(1), 149-167. doi:10.1080/13540602.2011.538506

Granberg, C. (2010). E-portfolios in teacher education 2002-2009: The social construction of discourse, design and dissemination. European Journal of Teacher Education, 33(3), 309-322. doi:10.1080/02619761003767882

Habowski, T., \& Mouza, C. (2014). Pre-service teachers' development of technological pedagogical content knowledge (TPACK) in the context of a secondary science teacher education program. Journal of Technology and Teacher Education, 22(4), 471-495. Retrieved from http://www.editlib.org/p/114605/

Hadley, N. J. (2007). The portfolio forum: Power in reflection. Journal of Educational Technology Systems, 35(4), 449-455. doi:10.2190/C521-U100-535U-7626

Herrington, J., \& Oliver, R. (2000). An instructional design framework for authentic learning environments. Educational Technology Research and Development, 48(3), 23-48. doi:10.1007/BF02319856

Hofer, M., \& Harris, J. (2012). TPACK research with inservice teachers: Where's the TCK? In P. Resta (Ed.), Proceedings of Society for Information Technology \& Teacher Education International Conference 2012 (pp. 4704-4709). Chesapeake, VA: Association for the Advancement of Computing in Education (AACE). 
Husu, J., Toom, A., \& Patrikainen, S. (2008). Guided reflection as a means to demonstrate and develop student teachers' reflective competencies. Reflective Practice, 9(1), 37-51. doi:10.1080/14623940701816642

Joyes, G., Gray, L., \& Hartnell-Young, E. (2010). Effective practice with e-portfolios: How can the UK experience inform implementation? Australasian Journal of Educational Technology, 26(1), 15-27. doi:10.14742/ajet.1099

Kabilan, M. K., \& Khan, M. A. (2012). Assessing pre-service English language teachers’ learning using eportfolios: Benefits, challenges and competencies gained. Computers \& Education, 58, 1007-1020. doi:10.1016/j.compedu.2011.11.001

Koehler, M. J., \& Mishra, P. (2008). Introducing TPACK. In AACTE Committee on Innovation \& Technology (Ed.), Handbook of technological pedagogical content knowledge for educators (pp. 3-29). New York, NY: Routledge.

Koehler, M. J., Mishra, P., \& Yahya, K. (2007). Tracing the development of teacher knowledge in a design seminar: Integrating content, pedagogy and technology. Computers \& Education, 49(3), 740-762. doi:10.1016/j.compedu.2005.11.012

Koh, J. H. L. (2013). A rubric for assessing teachers' lesson activities with respect to TPACK for meaningful learning with ICT. Australasian Journal of Educational Technology, 29(6), 887-900. doi:10.14742/ajet.228

Koh, J. H. L., \& Divaharan, S. (2013). Towards a technological pedagogical content knowledge-fostering information and communication technology instructional process for teachers: Lessons from the implementation of interactive whiteboard instruction. Australasian Journal of Educational Technology. 29(2), 233-247. doi:10.14742/ajet.97

Kopcha, T. J. (2012). Teachers' perceptions of the barriers to technology integration and practices with technology under situated professional development. Computers \& Education, 59(4), 1109-1121. doi:10.1016/j.compedu.2012.05.014

Lai, G., \& Calandra, B. (2010). Examining the effects of computer-based scaffolds on novice teachers'reflective journal writing. Educational Technology \& Development, 58, 421-437. doi: 10.1007/s11423-009-9112-2

Liao, C. W. (2011). Application of e-portfolio system to enhance teacher professional development. Educational Research and Reviews, 6(3), 251-258. Retrieved from http://www.academicjournals.org/journal/ERR/article-abstract/9A1E8BA4865

Lin, Q. (2008). Pre-service teachers' learning experiences of constructing eportfolios online. Internet and Higher Education, 11,194-200. doi:10.1016/j.iheduc.2008.07.002

Mair, C. (2012) Using technology for enhancing reflective writing, metacognition and learning, Journal of Further and Higher Education, 40 (2), 147-167. doi:10.1080/0309877X.2011.590583

Mansvelder-Longayroux, D. D., Beijaard, D., \& Verloop, N. (2007) The portfolio as a tool for stimulating reflection by student teachers. Teaching and Teacher Education 23, 47-62. doi:10.1016/j.tate.2006.04.033

Mishra, P., \& Koehler M. J. (2006). Technological pedagogical content knowledge: a framework for teacher knowledge. Teachers College Record, 108(6), 1017-1054. Retrieved from http://www.tcrecord.org/content.asp?contentid=12516

Moursund, D., \& Bielefeldt, T. (1999). Will new teachers be prepared to teach in a digital age? A national survey on information technology in teacher education. Beverly Hills, CA: Milken Family Foundation.

Orland-Barak, L. (2005). Portfolios as evidence of reflective practice: What remains 'untold'. Educational Research, 47(4), 25-44. doi:10.1080/0013188042000337541

Parkes, K. A., Dredger, K. S., \& Hicks, D. (2013). ePortfolio as a measure of reflective practice. International Journal of ePortfolio, 3(2), 99-115. Retrieved from http://www.theijep.com/pdf/IJEP110.pdf

Parkes, K. A., \& Kajder, S. (2010). Eliciting and assessing reflective practice: A case study in web 2.0 technologies. International Journal of Teaching and Learning in Higher Education, 22(2), 218-228. doi:10.4236/ce.2013.47a2010

Rickards, W. H., Diez, M. E., Ehley, L., Guildbault, L. F., Loacker, G., Hart, J. R., \& Smith, P. C. (2008). Learning, reflection, and electronic portfolios: Stepping toward an assessment practice. Journal of General Education, 57(1), 31-50. doi:10.1353/jge.0.0008

Riedinger, B. (2006). Mining for meaning: Teaching students how to reflect. In A. Jafari \& C. Kaufman (Eds.), Handbook of research on ePortfolios (pp. 90-101). Hershey, PA: Idea Group Publishing. doi:10.4018/978-1-59140-890-1.ch010 
Ritzhaupt, A., Ndoye, A., \& Parker, M. (2010). Validation of the electronic portfolio student perspective instrument (EPSPI): Conditions under a different integration initiative. Journal of Digital Learning in Teacher Education, 26(3), 111-119. doi:10.1080/10402454.2010.10784642

Schön, D. (1983). The reflective practitioner: How professionals think in action. New York, NY: Basic Books. doi:10.1016/0959-8022(94)90005-1

Shulman, L. S. (1986). Those who understand: Knowledge growth in teaching. Educational Researcher, 15(2), 4-14. doi:10.3102/0013189x015002004

So, H. J., \& Kim, B. (2009). Learning about problem based learning: Student teachers integrating technology, pedagogy and content knowledge. Australasian Journal of Educational Technology, 25(1), 101-116. doi:10.14742/ajet.1183

Strudler, N., \& Wetzel, K. (1999). Lessons from exemplary colleges of education: Factors affecting technology integration in preservice programs. Educational Technology Research and Development, 47(4), 63-81. doi:10.1007/bf02299598

Thornton, L. Ferris, N., Johnson, G., Kidwai, K., \& Ching, Y.-H. (2011). The impact of an e-portfolio program in a music education curriculum. Journal of Music Teacher Education, 21(1) 65-77. doi:10.1177/1057083710397592

Wakimoto, D. K., \& Lewis, R. E. (2014). Graduate student perceptions of eportfolios: Uses for reflection, development, and assessment. Internet and Higher Education, 21, 53-58. doi:10.1016/j.iheduc.2014.01.002

Wang, S. (2009). Inquiry-directed organization of e-portfolio artifacts for reflection. Elearning, 5, 419-433. Retrieved from http://www.ijello.org/Volume5/IJELLOv5p419-433Wang661.pdf

Yin, R. K. (2013). Case study research: Design and method (5th ed.). Thousand Oaks, CA: Sage Publishing.

Zeichner, K., \& Liu, K. (2010). A critical analysis of reflection as a goal for teacher education. In N. Lyons (Ed.), Handbook of reflection and reflective inquiry: Mapping a way of knowing for professional reflective inquiry (pp. 67-83). New York, NY: Springer. doi:10.1007/978-0-387-85744-2_4

Corresponding author: Yu-Hui Ching, yu-huiching@boisestate.edu

Australasian Journal of Educational Technology (c) 2016.

Please cite as: Ching, Y.-H., Yang, D., Baek, Y., \& Baldwin, S. (2016). Enhancing graduate students' reflection in e-portfolios using the TPACK framework. Australasian Journal of Educational Technology, 32(5), 108-122. https://doi.org/10.14742/ajet.2830 